\title{
MULHERES NA PUBLICIDADE: A DIVERSIDADE DE SENTIDOS EM ANÚNCIOS DE TV
}

\author{
WOMEN \& ADVERTISING: \\ DIVERSITY OF SENSES IN TV
}

\section{MUJERES EN LA PUBLICIDAD: LA DIVERSIDAD DE SENTIDOS EN LOS ANUNCIOS DE LA TV}

\section{Resumo}

\author{
Maria Cecília P. Katinskas ${ }^{1}$ \\ Mestranda em Comunicação da \\ Universidade Municipal de São Caetano do Sul (PMC/ USCS) \\ macepeka@ig.com.br \\ Roberta F. Esteves ${ }^{2}$ \\ Doutoranda em Publicidad y Relaciones Públicas \\ da Universitat Autònoma de Barcelona (UAB) \\ roberta.artepublicidade@gmail.com \\ Valéria Amoris ${ }^{3}$ \\ Mestre em Comunicação da \\ Universidade Municipal de São Caetano do Sul (PMC/ USCS) \\ valeria-amoris@uol.com.br \\ Priscila F. Perazzo ${ }^{4}$ \\ Docente do Programa de Mestrado em Comunicação da \\ Universidade Municipal de São Caetano do Sul (PMC/ USCS) \\ prisperazzo@ig.com.br
}

A publicidade pretende chegar ao consumidor por meio da apresentação de realidades diversas, mas que possam fazer sentido para o grupo que a assiste. Traz consigo aspectos culturais que visam agregar, questionar, revisar ou atualizar valores, comportamentos, relacionamentos, entre outros. Nesse sentido, esse artigo objetiva demonstrar a diversidade de sentidos dos códigos que aparecem nos anúncios publicitários. Trata-se de uma pesquisa documental e os anúncios analisados são dois filmes publicitários - criados para televisão e veiculados em 2010: "Fogão Amigo", da Nissin; e "Inversão de papéis", da Fiat - que tratam de questões relacionadas às mudanças no papel social das mulheres na sociedade contemporânea. Conclui-se que os sentidos dos anúncios são diversos e os códigos culturais podem ser acionados de formas ambíguas ou contrastantes.

Palavras-Chaves: Publicidade. Cultura, Semiótica. Mulher.

Esta obra está licenciada sob uma Licença Creative Commons 


\begin{abstract}
Advertising often reaches the consumer through the presentation of different realities, but makes sense for the group that attends. So, it brings the cultural aspects that aim stay together, ask questions, vise or update values, behaviors, and relationships, among others. So this article aims to demonstrate the diversity of meanings of codes that appear on TV commercials. This research is based on two commercials, created for television and showed in 2010: "Stove Friend" for instant Noodles line of Nissin, and "Role Reversal" to the new Fiat cars Sporting Idea. Both commercials deal with issues related to changes in contemporary society, particularly in regarding to the social role of women. The conclusion is that the senses in advertisements could be different, contrasting or ambiguous and depends on cultural codes triggered in several ways.
\end{abstract}

Key Words: Advertising. Culture, Semiotics. Woman.

\title{
Resumen
}

La publicidad ententa llegar al consumidor presentando diversas realidades, pero que pueden hacer sentido para el grupo que recibirá el mensaje. La publicidad trae consigo aspectos culturales que visan agregar, cuestionar, revisar o actualizar valores, comportamientos, relacionamientos, y otras cosas. En ese sentido, ese artículo objetiva enseñar la diversidad de sentidos de los códigos presentes en los anúncios publicitários. Se trata de una investigación documental y los anúncios analisados son dos propagandas creadas para la televisión y vehículadas en 2010: "Fogão Amigo" para la empresa Nissin; y “Inversão de papéis” para Fiat - que tratan de cuestiones relacionadas a lo papel social de las mujeres en la sociedad contemporanea. La conclusión es que los sentidos de los anúncios son diversos y los códigos culturales pueden ser accionados de maneras distintas, ambíguas o contrastantes.

Palablas Clave: Publicidad. Cultura. Semiótica. Mujer.

\section{INTRODUÇÃO}

A publicidade, muitas vezes, pretende chegar ao consumidor por meio da apresentação de realidades diversas, mas que possam fazer sentido para o grupo que a assiste. Para isso a publicidade traz consigo aspectos culturais que visam agregar, questionar, revisar ou atualizar valores, comportamentos, relacionamentos entre outros. É importante ressaltar que anúncios de televisão, por exemplo, têm poucos segundos para proceder ao processo comunicativo da publicidade. Além disso, ainda arca com a incumbência de relacionar a identidade do consumidor com o produto, acionar os valores desse consumidor, abordar e expor-lhe algo novo e interessante, fixar a marca. O antropólogo social Everardo Rocha, que estuda a publicidade, completa:

O domínio da produção se caracteriza claramente como um espaço de onde o homem se encontra alienado [...]. Mas produtos seriados, impessoais e anônimos deverão ser consumidos por seres humanos particulares [...]. O 
domínio do consumo é o da compra, da venda, das escolhas, dos negócios. É por excelência um "negócio" humano. Nele, a palavra fundamental é a troca. Homens, objetos, valores e dádivas são trocados, adquiridos e retribuídos. Na esfera do consumo, homens e objetos adquirem sentido, produzem significações e distinções sociais (ROCHA, 1985, p. 66-67).

Os anúncios seguem uma linha central delimitada, de antemão, entre o vendedor do produto e o publicitário que o anuncia. As agências de publicidade procuram resumir em uma frase a ideia âncora dessa linha central. Essa “primeira ideia” pode parecer aquela que determina um sentido único da mensagem que o anúncio deverá veicular e um sentido único que o consumidor ou espectador do anúncio de TV deverá entender.

Todavia, sabe-se, atualmente, que não encontramos somente sentidos únicos nos processos de comunicação e que o receptor pode compreender a mensagem de diversas formas, de acordo com os elementos variados que podem compor seu processo de leitura da publicidade. Da mesma maneira, no momento da criação do anúncio publicitário tantas outras mensagens podem ter sentido a partir da proposta definida no eixo temático. Se conseguirmos uma variedade de interpretações dos anúncios, poderemos perceber as diversas formulações de sentido que o receptor também poderá fazer, sem, contudo, achar que podemos contá-las por um número definido:

(...) é na esfera da elaboração e circulação dos discursos e dos sentidos que se produzem as representações sociais que vão fixar os sentidos e servir de modelo para a construção de identidades. (MENDONÇA, 2006, p. 34)

Por meio de uma reflexão interpretativa do conteúdo de filmes publicitários produzidos para televisão, podemos reconhecer diferentes sentidos da mensagem que está, de início no conceito do criador ou do produtor publicitário. Assim, questionamo-nos sobre a multiplicidade de interpretações possíveis veiculadas num anúncio. Ou seja, diversas informações e conceitos são transmitidos em anúncios publicitários, numa primeira percepção e outras interpretações resultam, posteriormente, da reflexão dos diversos códigos ${ }^{5}$ identificados na propaganda. As distintas interpretações possíveis para cada código apresentado nos anúncios deixam em questão a intencionalidade de cada anúncio. A busca pelas diversas interpretações às campanhas publicitárias não podem deixar de lado a subjetividade inerente ao comportamento humano:

De qualquer maneira, cada grupo social se empenha em manter semelhante persuasão em seus membros. Quantas pessoas têm espírito crítico o suficiente para discernir no que pensam a participação de outros, e para confessar para si mesmas que o mais das vezes nada acrescentaram de seu? 
(...) muitas vezes, a dosagem de nossas opiniões, a complexidade dos nossos sentimentos e gostos é apenas a expressão dos acasos que nos puseram em contato com grupos diversos ou opostos, e nossa parte em cada modo de ver é determinada pela intensidade desigual das influências que eles exerceram em separado sobre nós. (...) De qualquer maneira, à medida que detemos sem resistência a uma sugestão externa, acreditamos pesar e sentir livremente. É assim que em geral a maioria das influências sociais a que obedecemos permanece desapercebida por nós. (HALBWACHS, 2009, p. 65)

Diante da diversidade de assuntos gerados pela observação dos anúncios, como foi a recepção e/ou rejeição e interpretação do anúncio para os diversos públicos? Quais as diferentes mensagens que podem ser lidas? Que sentidos podem ser identificados num mesmo anúncio publicitário?

Seria audacioso analisar em apenas um artigo todo o processo de comunicação do anúncio publicitário para televisão. Assim, optamos por interpretar dois anúncios veiculados na TV brasileira em canais abertos, a fim de compreender a diversidade de sentidos que as mensagens podem ter, considerando-se dois momentos: o da criação e o da interpretação da mensagem. Os anúncios estudados são dois filmes publicitários de 30 segundos criados para televisão e veiculados em 2010. O primeiro tem como título “Fogão Amigo” e foi criado para a linha de macarrão instantâneo Miojo, da Nissin. E o segundo, chamado de "Inversão de papéis” corresponde ao lançamento do automóvel Novo Fiat Idea Sporting.

Assim, esse artigo objetiva apresentar a diversidade de sentidos dos códigos que aparecem nos anúncios publicitários nas campanhas ora escolhidas.

As mais diversas interpretações podem ser desenvolvidas. É necessário considerar que em todo o processo comunicativo, há de se atentar para os aspectos culturais do grupo ou da comunidade que se relacionará com o produto e com a publicidade, ou seja, o conjunto de códigos que serão apresentados ao receptor (espectador, público), e a decodificação desta mensagem resultante do universo cultural próprio dos receptores pois, apesar de presentes na mesma sociedade, a interpretação dos elementos que compõem a mensagem terá um aspecto individual.

Os valores que as pessoas possuem diferem uma das outras. Apesar da semelhança possível pela formação educacional, formação do imaginário e memória, advindos da sociedade em que vivemos, há diversos subgrupos nesta mesma sociedade, e que identificam valores e aspectos comuns peculiares ao grupo de pertencimento. Assim, um mesmo anúncio publicitário pode gerar entendimento totalmente diverso, de acordo com o público que o interpreta, pois como Martín-Barbero (2003, p. 157) relata: 
As relações da cultura com a comunicação têm sido freqüentemente reduzidas ao mero uso instrumental, divulgador e doutrinador. Essa relação desconhece a natureza comunicativa da cultura, isto é, a função constitutiva que a comunicação desempenha no processo cultural, pois as culturas vivem enquanto se comunicam umas com as outras e esse comunicar-se comporta um denso e arriscado intercâmbio de símbolos e sentidos.

Logo, o que queremos apresentar são as possibilidades de interpretação que estão nos dois anúncios selecionados. É preciso pensar sobre o conteúdo veiculado nos diversos tipos de anúncio para aperfeiçoar o senso crítico de tal tipo de produto midiático: a publicidade comercial. Em geral, pouca atenção é dada pelo público à reflexão sobre o anúncio, restandolhe, apenas, a relação com o produto. Todavia, a publicidade está inserida em nosso cotidiano se faz constante nos tempos atuais, tratando-se de um importante meio de comunicação com o qual nos relacionamos diariamente e, assim, produzimos diferentes sentidos de interpretação e entendimento, a partir de nossos valores e comportamentos, ou seja, nossos universos culturais.

O "multiculturalismo" é a resposta mais comum dada em nossos dias pelas classes ilustradas e formadoras de opinião para a incerteza do mundo sobre os tipos de valores que merecem ser apreciados e cultivados, e sobre as direções que devem ser seguidas com férrea determinação. (BAUMAN, 2001, p. 112)

\section{DESCRIÇÃO DOS ANÚNCIOS ESTUDADOS}

O filme "Fogão Amigo” tem direção de criação de Fábio Fernandes e Eduardo Lima, com criação da dupla André Faria e Keka Morelle, da F/Nazca S\&S. A produtora é a agência Hungry Man, que pela primeira vez, realiza um trabalho para a marca, sendo o filme assinado pelos norte-americanos Brian Billow e Gualter Pupo. O conceito do anúncio visa trazer um pouco do campo para a vida urbana das pessoas ao consumirem o macarrão instantâneo Miojo. A criação é reforçada com a locução em off "Ingredientes de verdade, do campo para a sua cozinha". Com 30 segundos de duração, o filme "Fogão Amigo", teve inserções previstas para intervalos comerciais das redes de televisão aberta Bandeirantes, Globo, Record e SBT.

As cenas iniciais chamam a atenção dos telespectadores: uma mulher jovem, aparentemente entre 20 e 30 anos, "pilotando" o fogão como se fosse um automóvel. Como uma mãe carinhosa que dirige no meio da plantação e colhe ingredientes frescos usados nas refeições que prepara para a família. De vestido branco, cabelos longos e soltos, ela dirige o 
“fogão-móvel” vermelho, colhe tomates, cebolas e outros ingredientes do gênero e os coloca diretamente na panela sobre o fogão com seis bocas com retrovisor e câmbio manual. Ao longo do seu trajeto por uma bela plantação de gêneros alimentícios, numa manhã ensolarada, com campos irrigados, a jovem dona de casa encontra-se com outras pessoas que pilotam fogões: um senhor agricultor passa por ela num fogão parecido com um trator, com volante e bule. Ainda no mesmo percurso, outra moça com características próximas a personagem central, no entanto, vestida com calças jeans. Na segunda cena, a moça de vestido branco, de volta ao lar, entra na cozinha com seu “fogão-móvel”, estacionando de ré, termina e serve o macarrão da Nissin Miojo como prato único e principal do almoço de sua família. O marido coloca a mesa e se sentam mãe, pai e filha para o almoço considerado saudável, natural, prático e de fácil preparo. O anúncio se conclui com a afirmação do slogan com locução em off "Ingredientes de verdade, do campo para a sua cozinha”. ${ }^{6}$

Já o anúncio “Inversão de papéis” tem como diretor de criação Ruy Lindenberg, e a dupla Renato Butori e Flavia Corradini da agência Leo Burnett, que assinam a direção de arte e redação. A produção do filme foi realizada pela Cine, com direção de Clóvis Mello. O conceito criado para o novo Fiat Idea é acompanhar as mudanças de atitudes perante o tempo. Nele aparece um homem na faixa dos 30 a 40 anos, como “pai de família”, com roupas modernas e descontraídas na cozinha, servindo o almoço para suas duas filhas, crianças de faixa etária aparentemente em torno de dez anos. Nesse momento, a esposa entra na sala, vindo do trabalho e, imediatamente, presentea-o com a chave de um carro. A família corre para frente da casa, onde o automóvel está estacionado. A esposa explica como o marido pode desfrutar do carro e ele a questiona se merece o presente. Nesse momento, o casal de vizinhos os observa e ficam boquiabertos com a cena que assistem. O conceito sobre a inversão de papéis é reforçado com a locução em off “O mundo mudou. O Idea também.”

Dois filmes de 30 segundos foram criados e entraram no ar em 12 de agosto de 2010. O primeiro filme foi “Inversão de Papéis" e o segundo chamou-se “Ilusões”, abordando o conceito de mudança sobre outra perspectiva: o mundo real e o imaginado. Tecnicamente explorou o design e a tecnologia 3D. A câmera mostra os detalhes do carro, numa cena fechada, e filma um homem jovem que, ao sair de um prédio, se depara com o seu Novo Idea Adventure e passa a imaginar situações de aventura em meio a bichos e objetos. O vídeo apresenta cenas do centro velho da cidade de São Paulo.

Por sua vez, não pretendemos interpretar o segundo filme produzido para a publicidade do Idea. Deteremo-nos no anúncio “Inversão de Papéis” como nosso objeto de 
estudo, pois aborda questões comportamentais relativas ao papel da mulher na sociedade, bem como o anúncio “Fogão Amigo”, para a campanha da Nissin Miojo.

\section{MULHERES E PUBLICIDADE}

A seleção desses anúncios se caracterizou pela expressão imediata de dois papéis sociais diferentes para as mulheres: a "dona de casa que pilota o fogão" e a "executiva, chefe de família”. Numa observação perfunctória, o anúncio “Fogão Amigo” gera a interpretação de uma família tradicional, em que a mulher é a responsável por garantir as condições de uma vida saudável para a sua família, e cabem a ela os serviços domésticos como a preparação do almoço. O anúncio “Inversão de Papéis” apresenta outra condição para a mulher: trabalhadora, responsável pela renda familiar, deixando a cargo do marido as funções do serviço doméstico, como servir o almoço e cuidar das crianças. Contudo, em uma análise mais detalhada, outras interpretações podem ser apresentadas.

Com base em alguns conceitos da teoria da Semiótica Sistêmica, desenvolvida pelo semiotissista Iuri Lótman para compreender a cultura e sociedade, que serão utilizados na análise dos textos dos anúncios, buscamos as diversas interpretações possíveis dos elementos das publicidades acima mencionadas, com base nos diferentes códigos culturais, definidos por Irene Machado (2003, p.156) como:

Estruturas de grande complexidade que reconhecem, armazenam e processam informações com um duplo objetivo: regular e controlar as manifestações da vida do bio, do socius, do semeion. Os códigos culturais constituem um vocabulário mínimo da cultura, sempre em movimento. [...] os seres humanos não somente se comunicam com signos como são em larga medida, controlados por eles.

A importância do aspecto da interpretação dos códigos culturais pode ser percebida pelos estudos realizados por Márcia P. Tondato. Segundo a autora, o consumo é uma manifestação dos valores individuais - externalização da individualidade.

Para compreender a leitura dos anúncios feita pelos receptores e, no caso deste estudo, sua relação com a constituição de identidade das mulheres das classes populares, é preciso partir da combinação de sinais - imagéticos e textuais - constituintes dos signos veiculados nas mensagens, buscando as decodificações feitas pelos discursos destas mulheres. Os discursos decodificados não serão os mesmos emitidos pela fonte. Mesmo que os meios sejam, até certo ponto, estruturantes, utilizando-se de sinais determinados, na intersecção emissão-recepção-contexto, são estabelecidos aspectos ideológicos, refletindo e refratando o momento da recepção, que pode atender a outras necessidades que não aquelas colocadas pelo emissor, 
necessidades de reconhecimento e integração, sim, mas também de resistência e contestação. (TONDATO, 2010, p.101)

Logo, o consumo dependerá de como os anúncios foram interpretados para que o produto faça parte da provável demanda de cada pessoa. Se houver identificação com o anúncio, este será objeto de consumo dos indivíduos e a identificação depende da interpretação da mensagem, a qual está sujeita aos códigos culturais (de acordo com o grupo de pertencimento), em relação aos signos visuais e auditivos apresentados pelo anúncio.

Observamos que ambos os conceitos das peças publicitárias utilizaram como pressuposto estratégico a imagem da mulher como protagonista de sua própria vida e da situação que se encontra, buscando seja a realização familiar ou profissional ou a condição de dona de casa ou gestora do lar. Baseando-se em Gonçalves e Nishida (2009), os publicitários resgatam aspectos do estilo de vida da mulher contemporânea e inseriram nas personagens dos anúncios, seu modo de ser e de viver. Ainda, de acordo com essas autoras, as mulheres nos dias de hoje estariam em consonância com o modo de ser das personagens dos anúncios: "Podemos refletir que em relação à preservação das faces tanto a positiva como a negativa do enunciador e coenunciador foram valorizadas” (GONÇALVES e NISHIDA, 2009, p. 63).

Lotman coloca que "en el sistema de la cultura los textos cumplen por lo menos dos funciones básicas: la trasmisión adecuada de los significados y la generación de nuevos sentidos” (1998, p.94). Compreendendo que o público no qual recebe a mensagem publicitária pode ir além do significado da peça publicitária, podendo ter uma resposta a mensagem até de forma inesperada, ou até mesmo negativa.

Considerando o assunto abordado nessas duas campanhas publicitárias, os receptores das mensagens podem se identificar com o que está representado, visto que os anúncios se apresentam de acordo com as características culturais e sociais do contexto em que estão inseridos:

Ao mesmo tempo que a publicidade aconselha modos de adaptação à vida contemporânea, sugere mudanças de atitudes, estilos de vida vinculados à utilização do produto oferecido; ela também se apresenta como um meio que veicula práticas, atitudes e comportamentos que nem sempre estão em consonância com os princípios ético-morais. Ou seja, práticas que nem sempre partem da reflexão sobre o "dever ser" das relações nelas envolvidas ou envolvidas a partir delas. (GONÇALVES e NISHIDA, 2009, p. 69, 70)

As representações dos estilos de vida, dos desejos, dos modos de ser das pessoas materializadas nas propagandas, constituem uma significação ética que remete a uma preocupação ética. Uma representação é uma versão de um fato, podendo ser, ao mesmo 
tempo, uma sugestão, um reforço a determinados comportamentos e situações (GONÇALVES e NISHIDA, 2009). Assim, diversos elementos podem ser observados e analisados nos dois anúncios, tanto no sentido da interpretação mais óbvia do senso comum, quanto em perceber contrastes e ambiguidades nesse sentido comum.

\section{4 “PILOTAR O FOGÃO” OU DIRIGIR SUA AGENDA DOMÉSTICA?}

No anúncio “Fogão Amigo”, há a representação do ambiente bucólico: um campo em que algumas pessoas colhem legumes. Ao fundo, toca uma música cantada em língua inglesa. É um vasto campo de agricultura irrigada. A jovem mulher pilota o “fogão-móvel”, que é vermelho - cor que geralmente são os carros das mulheres. O fogão tem seis bocas - o que normalmente têm as pessoas que gostam ou tem o hábito de cozinhar, sobretudo quando se cozinha para muitas pessoas ou famílias grandes. O comando do fogão é realizado pelas laterais, como guidões de motos. Outros personagens dirigem fogões também, nessa mesma cena, mas os outros "fogões-móveis” têm quatro bocas. O único homem que aparece pilotando o fogão é uma pessoa com mais idade que a protagonista do anúncio e está pilotando um fogão com volante. Os objetos sobre o fogão são panela e bule esmaltados (fogão pilotado pelo homem e pela protagonista) de uso comum. O traje da personagem principal se caracteriza por um vestido branco, ao estilo das camponesas norte-americanas das décadas de 1950-1960, um tom bucólico que se completa com o cenário e a trilha sonora do filme.

Na cena, podemos apontar diversos elementos duais: a dona de casa, que prepara a refeição da família é que "pilota o fogão", numa alusão direta ao tradicionalismo da estrutura familiar, baseada na figura da dona de casa que zela por sua família. Ela é jovem e simples, cumpre sua tarefa doméstica com calma e demonstrando muita satisfação por cuidar da alimentação da sua família. Vê-se tal cena, a priore, como a de uma dona de casa tradicional, que "pilota o fogão”, na gíria popular, e está longe das preocupações das mulheres chamadas "modernas", ou seja, aquelas que trabalham fora de casa, possuem diversos compromissos e, constantemente, devem fazer escolhas com relação às suas atividades diárias e não se apresentam com um ar tão sereno e tranqüilo diante do trabalho doméstico.

Por sua vez, pode-se interpretar essa cena de uma forma diferente. A característica do produto vem ao encontro da idéia de incorporar aos hábitos familiares o consumo de alimentos semi-prontos, ágeis e rápidos de preparar, como o caso do macarrão instantâneo. 
Essa é uma demanda da vida urbana, agitada e, muitas vezes, das pessoas que trabalham fora de casa e têm pouco tempo para prepararem suas refeições ou as da família. A protagonista do filme do anúncio é jovem, bem arrumada em relação ao estilo apresentado e motorista de automóvel vermelho. Tem habilidades na cozinha e na direção de carros, demonstradas inclusive ao estacionar seu "fogão-móvel” de ré, ao chegar a sua cozinha. Alguns desses atributos caracterizam as donas de casa nos dias atuais

Aprofundando a interpretação, pode-se dizer que os elementos culturais que aparecem na cena foram abordados de forma dicotômica: a mulher pilota um fogão, mas esse fogão é um automóvel vermelho. Trata-se de uma imagem tradicional do papel da mulher, mesclada por elementos da emancipação feminina: o ato de dirigir (sejam os objetos a serem dirigidos: automóveis, ônibus, trens, caminhões, navios, empresas, residências, etc.). É uma abstração do espaço social que a mulher está diariamente conquistando, sem perder a noção de que é ela que realmente "dirige” as tarefas domésticas e "toma decisões”, mesmo tratando-se de um ambiente doméstico.

A imagem da dona de casa que dirige seu “auto-fogão-móvel” e entra de ré com ele para estacioná-lo na cozinha, como se fosse sua garagem, contradiz o paradigma do senso comum de que as mulheres mal sabem fazer as manobras com os carros.

Outro elemento a ser interpretado, de forma figurada, é que o lar significa o "lugar” de estabilidade, de refúgio e que as atribuições da vida moderna devem ficar fora do ambiente saudável que é a vida em família. Assim, a refeição familiar, o que não caracteriza as relações dos grandes centros urbanos, torna-se possível de forma saudável e aconchegante quando se tem um produto de fácil e rápido preparo como o Miojo Nissin. Isso significa que, a imagem imediatamente associada ao jargão pejorativo de que "mulher pilota fogão" pode ser recolocado noutro contexto, em que a mulher dos tempos atuais dirige sua vida doméstica, a fim de manter a vida saudável que o antes se conseguia no ambiente bucólico e campestre do passado.

A personagem também não se remete ao padrão observado na realidade brasileira. Está bem arrumada, mesmo que de cabelos soltos e um simples vestido branco. A imagem nos remete a uma memória adquirida pelos filmes hollywoodianos em que esse era o padrão de camponês. A música cantada em língua inglesa e o estilo country reforçam essa ideia de um universo simbólico norte-americano, que transmite um ar bucólico e também tradicionalista do período que, para nós, brasileiros, não foi vivido, mas temos como referência em nossa memória e por consequência absorvemos esses códigos culturais. 
Segundo Irene Machado:

Do ponto de vista semiótico, a cultura desenvolve-se com memória coletiva por abarcar a historicidade dos sistemas dos signos, uma vez que se relaciona com a história passada [...] Cultura é a memória ou gravação na memória do patrimônio vivencial da coletividade; enquanto tal, reporta-se ao passado. (MACHADO, 2003, p. 163)

O efeito da globalização também pode ser percebido nessa campanha publicitária Miojo, macarrão de origem oriental, músicas, estilo da cozinheira, vestimentas etc. ampliando as possibilidades de interpretações possíveis:

"Os fluxos culturais, entre as nações, o consumismo global criam possibilidades de "identidades partilhadas" - como "consumidores” para os mesmos bens, clientes para os mesmos serviços, "públicos” para as mesmas mensagens e imagens - entre pessoas que estão bastante distante umas das outras no espaço e no tempo. À medida em que as culturas nacionais tornamse mais expostas a influências externas, é difícil conservar as identidades culturais intactas ou impedir que elas se tornem enfraquecidas através do bombardeamento e da infiltração cultural” (HALL, 2006; p. 74).

\section{INVERTER OS PAPÉIS OU BUSCAR A IGUALDADE DE GÊNERO?}

O anúncio "Inversão de Papéis”, produzido para a campanha do novo Fiat Idea pretende, de antemão, abordar a questão do “moderno” nos comportamentos familiares.

Apresenta outro tipo de mulher relacionado à figura da dona de casa. Induz que, nesse caso, houve uma conquista social para as mulheres: são elas que trabalham fora de casa e ganham o suficiente para presentear o marido com um carro novo. Os personagens aqui caracterizam mesmo um estereótipo de “inversão de papéis”, pois é o marido quem está em casa cumprindo as tarefas domésticas de preparar e servir a refeição das filhas.

Inicialmente, a mensagem do anúncio parece propor a conquista da emancipação feminina, ao colocá-la nas mesmas posições dos homens, ou seja, fazer o que eles faziam no passado: trabalhar fora, ser um profissional executivo que traja roupas formais como ternos e ganha um salário suficiente para prover a família, bem como para comprar um automóvel. Além de ser aquele que pode comprar, também é aquele que decide qual automóvel comprará. E a esposa é surpreendida pelo novo carro que chega ao momento em que ela cumpre suas tarefas domésticas. No entanto, no anúncio “Inversão de papéis” as figuras estão invertidas: a mulher exerce os papéis antes masculinos e o esposo os papéis antes femininos. O marido é presenteado com o Fiat Idea pela esposa que o recompensa com o novo carro para que ele 
possa fazer compras e levar as filhas à escola. E, ainda, levar os amigos para jogar futebol. A estupefação do marido é tal que ele pergunta: Eu mereço?

Tal inversão pode fazer parte de um processo de fragmentação, descentração e dificuldade de identificação e pertencimento:

\begin{abstract}
um tipo de mudança estrutural está transformando as sociedades modernas no final do século XX. Isso está fragmentado nas paisagens culturais de classe, gênero, sexualidade etnia, raça e nacionalidade, que no passado, nos tinham fornecido sólidas localizações como indivíduos pessoais, abalando a idéia que temos de nós próprios como sujeitos integrados. Esta perda de um "sentido de si" estável é chamada, algumas vezes, de deslocamento ou descentração do sujeito. Esse duplo deslocamento - descentração dos indivíduos tanto de seu lugar no mundo social e cultura quanto de si mesmos - constitui uma “crise de identidade” para o indivíduo.” (HALL, 2006; p. 9)
\end{abstract}

A mulher chega vestida num traje clássico executivo, estilo terno, na cor preta, cabelos presos, salto alto nos sapatos, estereotipando a figura masculina do executivo, chefe de família, bem sucedido economicamente. A residência é ampla e pela locomoção dos personagens para a garagem indica ser uma casa em que não há portões fechando a frente, onde se pode estacionar o carro. A mulher representa a figura que na família ocupa cargos mais elevados no emprego e ganha um salário maior, enquanto o homem cuida da casa, das filhas e das refeições. A personagem aparece como chefe de família no que se refere à geração de renda.

Ao questionar se merece o presente, o marido indica uma queixa do senso comum, feita normalmente pelas donas de casa que são pouco lembradas quanto à importância de seu papel nas tarefas cotidianas familiares e domésticas, retomando uma visão conservadora da família.

Por fim, um casal de vizinhos observa o momento em que o presenteado está recebendo o carro. Aparentemente descontraídos, de quem está em casa sem compromisso, o homem com barba por fazer e a mulher com cabelo não arrumado, assistem a cena e ficam boquiabertos diante do que vêem acontecer com a família do vizinho, indicando que essa inversão de papéis entre homem e mulher lhes é estranha como comportamento usual. O homem vizinho, ao observar o presente ganho pelo outro, diz para a própria esposa, no momento em que a moça tenta lhe dar explicações sobre a situação: "Não fala nada, não. Preciso ficar um pouco sozinho”. Para esse epílogo do anúncio, diversas interpretações são possíveis: ele não entende como os valores são diferentes dos que ele vive; ou ele também gostaria de viver essa situação de papéis invertidos para poder ganhar o mesmo carro; ou, ainda, ele gostaria que a esposa o valorizasse a ponto de lhe dar um carro também. Afinal, 
segundo Stuart Hall (2006, p. 7) "as velhas identidades, que por tanto tempo estabilizaram o mundo social, estão em declínio, fazendo surgir novas identidades e fragmentando o individuo moderno (...).”

Apesar de apostar em imagens que indiquem situações cotidianas mais contemporâneas, a propaganda gera um desconforto, pois apenas inverteram-se os papéis sociais entre os gêneros, mas não necessariamente se conquistou direitos igualitários entre os gêneros. O papel que era tradicionalmente do homem, passou para a mulher sem a evolução da responsabilidade compartilhada de forma a respeitar as diferenças individuais. Não mostra uma conquista da igualdade entre as pessoas com respeito as diferenças, mas sim a supremacia antes exercida pelos homens, agora invertida em superioridade feminina sobre a masculina.

A música, de fundo, se modifica ao longo do anúncio (de canção popular com violão para o rock), o que indica mais o confronto (devido às características dos estilos musicais) que, propriamente, um avanço social no campo das diferenças de gêneros.

Novamente, a imagem do automóvel vermelho retorna à cena, pois o Fiat Idea presenteado também é vermelho e tem a figura feminina como protagonista das escolhas do automóvel. Algumas características permanecessem presentes, quando se trata de consumo voltado ao público feminino: ambos os anúncios (Fogão Amigo e Inversão de Papéis) invocam a mulher no ambiente doméstico e os estereótipos tradicionais e contemporâneos do universo cultural feminino (TONDATO, 2010).

Logo, interpretações possíveis resultam da análise das propagandas e sua linguagem simbólica, sem deixar de lado o momento de transformação e reorganização que permeia a sociedade atual. Sendo assim, a "leitura” que o público faz das mensagens existentes em cada campanha publicitária demandaria um segundo trabalho de estudo de recepção.

\section{CONSIDERAÇÕES FINAIS}

Os dois anúncios analisados nesse artigo tratam de questões relacionadas às mudanças na sociedade contemporânea, sobretudo no que diz respeito ao papel social das mulheres. Por um lado, tratam de valores tradicionais e conservadores, como no anúncio "Fogão Amigo" da Nissin que retrata a mulher como dona de casa zelosa. Em outro, traz uma nova posição da mulher nas relações familiares, como no anúncio do Fiat Idea “Inversão de papéis”. Em ambos, há mensagens e valores que, aparentemente, estariam em consonância com o senso 
comum e com o momento social, seja na manutenção do papel tradicional da mulher na sociedade ou na ânsia de transformação desse papel.

Mas, diante do que se propôs com essa análise - demonstrar a diversidade de sentidos, dos valores e dos códigos culturais que aparecem nos anúncios publicitários - o que pudemos perceber é que a ideia inicial dos anúncios pode ser interpretada de forma inversa ao que cada anúncio parecia propor de imediato.

Em “Fogão Amigo”, alguns símbolos, delicada e sutilmente, nos remetem a um outro universo feminino. De forma ambígua, tanto o papel tradicional da mulher dona de casa e responsável pelo bem estar da família está evidente, quanto os elementos que indicam que a mulher dirige sua própria vida, faz suas escolhas e não depende dos homens para suas próprias manobras. Afinal, ambos códigos ainda existem na sociedade contemporânea, pois as mulheres ainda são donas de casa, da mesma forma que dirigem suas próprias vidas. Assim, a mulher que pilota o fogão (como "pilota” o carro) é uma imagem ambígua que permite diferentes códigos culturais de identificação e identidades sociais.

O mesmo acontece com o anúncio “Inversão de papéis”, cujo título já evidencia o que se pretendeu apresentar. O que ocorre nessa situação imagética, idealizada no anúncio, não é, necessariamente a emancipação da mulher e a conquista de uma sociedade igualitária entre os diferentes gêneros. É mesmo uma inversão de papéis sociais quando a mulher apenas troca de lugar com o homem, mas continua-se a reproduzir a hierarquia entre os sexos e a opressão entre os gêneros.

Portanto, o que se compreende no universo publicitário é que podemos inverter imagens e ou mantê-las nos seus sentidos tradicionais, o que não significa que seus sentidos e interpretações garantam as mensagens inicialmente idealizadas pelos seus criadores. Mesmo antes de analisarmos os sentidos que os receptores podem dar aos anúncios publicitários que assistem, já percebemos o quanto os sentidos são diversos e os códigos culturais podem ser acionados de diversas maneiras: diferentes, mas também ambíguas ou contrastantes.

\footnotetext{
${ }^{1}$ Aluna do Programa de Mestrado em Comunicação da Universidade Municipal de São Caetano do Sul (PMC/ USCS). Graduada em Ciências Econômicas (Mackenzie - 1991/95). E-mail: macepeka@ig.com.br

2 Doutoranda do curso de Publicidad y Relaciones Públicas da Universitat Autònoma de Barcelona (UAB). Mestre pelo Programa de Mestrado em Comunicação da Universidade Municipal de São Caetano do Sul (PMC/ USCS) - pesquisa desenvolvida com auxílio de Bolsa Fapesp; graduada em Comunicação Social com Habilitação em Publicidade e Propaganda (USCS - 2002/ 05). E-mail: roberta.artepublicidade@gmail.com ${ }^{3}$ Mestre pelo Programa de Mestrado em Comunicação da Universidade Municipal de São Caetano do Sul (PMC/ USCS) - pesquisa desenvolvida com auxílio de Bolsa CAPES; graduada em Comunicação Social com Habilitação em Jornalismo (USCS - 1999/2002). E-mail: valeria-amoris@uol.com.br
} 
4 Docente do Programa de Mestrado em Comunicação da Universidade Municipal de São Caetano do Sul (PMC/ USCS) - Doutora em História Social; Coordenadora do Laboratório Hipermídias/Memórias do ABC da USCS. E-mail: prisperazzo@ig.com.br

${ }^{5} \mathrm{O}$ conceito de código empregado no presente artigo se remete ao desenvolvido por Lotman na teoria da Semiótica da Cultura, sendo código um "signo convencional ou uma organização de caráter genérico a partir da qual é possível a constituição dos sistemas” (MACHADO, 2003, p. 155).

${ }^{6} \mathrm{O}$ anúncio pode ser assistido no endereço:

http://www.portaldapropaganda.com/vitrine/tvportal/2010/04/0012.

${ }^{7} \mathrm{O}$ anúncio pode ser assistido no endereço:

http://www.portaldapropaganda.com.br/portal/noticias/20547-campanha-do-novo-fiat-idea-destaca-inovacoesde-comportamento-do-consumidor.

\section{REFERÊNCIAS}

BAKHTIN, M. Mikhail. Estética da criação verbal. São Paulo: Martins Fonte, 1997.

BAUMAN, Zygmunt. Comunidade: A busca por segurança no mundo atual. Rio de Janeiro: Jorge Zahar Ed., 2003.

GONÇALVES, M. Elizabeth; NISHIDA, F. K. Neusa. Publicidade e ética: um estudo da construção da imagem da mulher. Comunicação, Mídia e Consumo/Escola Superior de Propaganda e Marketing. V. 6, n 17 (novembro de 2009) - São Paulo: ESPM, 2009, p. 63, 69, 70.

HALBWACHS, Maurice. A memória coletiva. São Paulo: Centauro, 2006.

LOTMAN, Iuri M. La Semiosfera: Semiótica de la cultura y del texto. Madrid: Cátedra, 1998.

MACHADO, Irene. Escola de Semiótica: A Experiência de Tártu-Moscou para o Estudo da Cultura. São Paulo: Ateliê Editorial, 2003.

MENDONÇA, Maria Luiza. Comunicação e cultura: um novo olhar. In: SOUZA, Mauro Wilton de (org). Recepção mediática e espaço public. Novos olhares. São Paulo: SEPAC/Paulinas, 2006.

MARTÍN-BARBIRO, Jesús. Globalização comunicacional e transformação. In: Moraes, Denis de (org.). Por uma outra comunicação: mídias, mundialização cultural e poder. Rio de Janeiro: Record, 2003.

ROCHA, Everardo G. Magia e Capitalismo. São Paulo: Brasiliense, 1985.

HALL, Stuart. A identidade na pós-modernidade. 11 ed. Rio de Janeiro: DP\&A, 2006.

TONDATO, Márcia P. Comunicação e o Consumo: representações identitárias da mulher na publicidade do prime-time. Revista Eco-Pós, v. 13, n. 3- São Paulo: 2010, dossiê, p. 82-104. Consulta em 02/08/2011. Disponível em: http://www.pos.eco.ufrj.br/ojs-2.2.2/index.php/revista/index 


\section{ANÚNCIOS}

Fogão Amigo, campanha do Macarrão Instantâneo Nissin Miojo, que a F/Nazca S\&S. Disponível em: http://www.portaldapropaganda.com/vitrine/tvportal/2010/04/0012. Acessado em 01/11/2010.

Inversão de Papéis, campanha do carro Fiat Idea. Disponível em:

http://www.portaldapropaganda.com.br/portal/noticias/20547-campanha-do-novo-fiat-idea-destacainovacoes-de-comportamento-do-consumidor. Acessado em 01/11/2010.

Original recebido em: 03/07/2012

Aceito para publicação em: 20/07/2013

Resumo dos autores:

${ }^{1}$ Priscila Perazzo é docente do Programa de Mestrado em Comunicação da Universidade Municipal de São Caetano do Sul (PMC/ USCS) - Doutora em História Social; Coordenadora do Memórias do ABC - Núcleo de Estudos e Laboratório de Produções Midiáticas da USCS.

2 Roberta Esteves é aluna do Programa de Mestrado em Comunicação da Universidade Municipal de São Caetano do Sul (PMC/ USCS) - pesquisa desenvolvida com auxílio de Bolsa Fapesp; graduada em Comunicação Social com Habilitação em Publicidade e Propaganda (USCS - 2002/ 05)

${ }^{3}$ Valéria Amoris é aluna do Programa de Mestrado em Comunicação da Universidade Municipal de São Caetano do Sul (PMC/ USCS) - pesquisa desenvolvida com auxílio de Bolsa CAPES; graduada em Comunicação Social com Habilitação em Jornalismo (USCS - 1999/2002).

${ }^{4}$ Maria Cecília Katinskas é Aluna do Programa de Mestrado em Comunicação da Universidade Municipal de São Caetano do Sul (PMC/ USCS). Graduada em Ciências Econômicas (Mackenzie 1991/95). 